\title{
Small bowel update. Part I
}

\author{
J LOVE, ABR THOMSON, MD, PHD, FRCPC, FACP
}

\author{
J Love, ABR Thomson. Small bowel update. Part I. Can J Gastroenterol \\ $1992 ; 6(1): 44-56$.
}

Key Words: Brush border membrane, Enterocytes, Intestinal ischemia, Nutrients, Short bowel syndrome, Small bowel
$\mathrm{T}$ HE RECENT ADVANCES IN CLINIcally important diseases of the small intestine have been reviewed; however, the basis for many of these clinical advances rests with important observations on alterations in the physiology of the small intestine, as well as mechanistic observations of alterations in small intestinal function in models of human disease. In this review, a summary of the past year's literature is presented, which will draw attention to the considerable areas of progress in small bowel physiology soon to be translated into an improved understanding of the pathophysiology of a variety of intestinal disorders.

\section{INTESTINAL GROWTH AND THE SHORT BOWEL SYNDROME}

The polyamines (putrescine, spermine and spermidine) are ubiquitous polycationic compounds synthesized by all nucleated cells and are required for cell growth initiation and differentiation. Polyamines may exert their effect on cellular growth by stimulation of the $\mathrm{Na}^{+} / \mathrm{H}^{+}$exchange in the intestinal mucosa of rats (1). Polyamines are involved in a variety of biochemical processes leading to increased mucosal DNA, RNA and protein content. Polyamine biosynthesis in mammalian cells is regulated mainly by ornithine decar-
Division of Gastroenterology, Department of Medicine, University of Alberta, Edmonton, Alberta

Correspondence and reprints to Dr ABR Thomson, 519 Robert Newton Research Building, University of Alberta, Edmonton, Alberta T6G 2C2. Telephone (403) 492-6490, Fax 403 $492-7964$

Received for publication August 26, 1991. Accepted January 28, 1992 boxylase (ODC) and by S-adenosyl. methionine decarboxylase. Inhibition of ODC by $\alpha$-difluoromethylornithine blocks cell growth. ODC activity chan. ges rapidly in response to various stimuli (such as feeding) and also is influenced by its end product, putres. cine. Enzymatic activities are relatively low in nonproliferating tissues and are highly inducible in response to trophic stimuli, invoking a complex array of signalling mechanisms with ODC induction during transcription or pos transcriptional enzyme regulation. In cultured intestinal epithelial crypt cells, ODC is regulated at multiple levels by independent signalling path. ways. There are also different signalling pathways controlling mRNA levels (compared with those involved in translational and degradative proces. ses) (2). Putrescine's effect on ODC activity depends on where the entero. cytes are obtained along the villus (3), because ODC of nonproliferating villus cells are regulated differently from ODC in proliferating crypt cells.

Rat duodenum and jejunum contains 2 to $3 \mathrm{mM}$ putrescine and 1 to 2 $\mathrm{mM}$ cadaverine, while the concentrations of these polyamines are lower in 
the ileum and colon (4). Jejunal fluid polyamine levels may reflect mucosal polyamine content. The high concentration of putrescine in the proximal intestine arises from production in the colon and transport of the putrescine to the proximal intestine via enterohepatic circulation. In patients with previous intestinal resections, putrescine and spermidine concentrations in the jejunostomy effluent increase after refeeding; these changes are correlated with intestinal remnant length and carbohydrate absorption (5). Increased mucosal ODC activity is stimulated by glucose and amino acids with the highest concentration of ODC and polyamines in the villus tip cells.

In humans, as in rodents, the small intestinal mucosa contains the highest activity of diamine oxidase (DAO) (located in the cytosol fraction of mature differentiated enterocytes). DAO may affect putrescine metabolism, which in turn regulates nucleic acid synthesis and, ultimately, cellular proliferation. After jejunectomy in rats, the remaining ileum hypertrophies and the residual intestinal DAO activity reflects this quantitaivive change of the mucosal mass. In the ileum of both resected and transsected rats there is a correlation between total DAO activity and either mucosal weight or DNA concentration. Thus, circulating DAO levels might be used as a marker of ileal mucosal adaptation (6). Also, the measurement of serum DAO reflects reduced post heparin plasma DAO levels in patients with villus atrophy or Crohn's disease. A single assay at $1 \mathrm{~h}$ after $15,000 \mathrm{~mL}$ injection of heparin may be useful in monitoring small bowel enterocyte mass recovery in patients with small bowel disease (7).

The intestinal mucosa begins as undifferentiated progenitor cells in the crypts and progresses orderly to mature multifunctional cells in the villus. The growth factors and their interactions, however, remain to be unravelled. Extracellular factors modulating mucosal growth and differentiation include extracellular matrix proteins, epidermal growth factor (EGF) and transforming growth factors (TGF- $\alpha$ and TGF- $\beta$ ). TGF- $\alpha$ structurally is homologous to
EGF, stimulates cellular proliferation and may be present largely in the villus cells. TGF- $\beta_{1}$ inhibits cellular proliferation, may induce intestinal cultured epithelial crypt-6 cell differentiation and has mRNA transcripts and activities in crypt cells (8). Some workers (9), however, have not confirmed the differential expression of TGF- $\beta$ along the crypt-to-villus axis.

A growth inhibitor - a low molecular weight protein inhibiting the proliferation of IRD-98 epithelial cells in a reversible manner and arresting cells in phase $\mathrm{G} 1$, of the cell cycle has been identified in the villus extract from the supernatant preparation obtained from human intestinal epithelial cells (10).

Noradrenergic nerve nets surround the bases of the intestinal crypts. Receptors of the $\alpha 2$-adrenoceptor class have been detected on isolated intestinal cells, including crypt cells. Noradrenaline promotes cell proliferation in the jejunal crypt epithelium due to stimulation of an $\alpha$-adrenoceptor. Desipramine, an inhibitor of noradrenaline uptake, accelerates crypt cell proliferation in intact (but not in chemically sympathectomized) rats, adding support to the suggestion that crypt cell division regulation is a function of the sympathetic nervous system (11).

Short chain fatty acids (SCFAs) such as acetic, proprionic and butyric acids are major products of colonic fermentation and may stimulate epithelial proliferation. The SCFAs are trophic on the intestine without direct luminal contact or without efferent transmission by nerves in the mesentery which suggests a blood-borne effect (12).

The addition of guar to a solid-liquid meal alters the composition and volume of chyme at the midintestine of dogs with midintestinal fistulas, disrupts gastric sieving and reduces triolein absorption from 88 to $38 \%$ (13). The addition of dietary fibre to a lowresidue diet has a favorable effect on maintenance of intestinal architecture and function during enteral feeding; plasma DAO can be used as an index of functional and/or structural changes occurring in the small intestine during enteral or parenteral feedings (14).

\section{NUTRITIONAL IMPACT OF} SMALL BOWEL RESECTION

Malabsorption, nutritional status and support $(15,16)$, total parenteral nutrition (17), enteral nutrition and its potential role in regulating immune function (18), and the use of elemental diets in the prophylaxis and therapy for intestinal lesions (including those following radiation injury [19]), have been reviewed.

Animals undergoing distal small bowel resection (DSBR) initially suffer from diarrhea which diminishes due to morphological and functional adaptive changes in the remnant small and large intestine. Included in these functional changes are increases in intestinal transport capacity, specific activity for sodium, chloride and water, and mucosal permeability. Increased net fluid absorption also occurs in the large intestine after DSBR (20), with loosening of tight junctions and decreased mucosal cAMP and cGMP levels. Diarrhea following DSBR may result from the malabsorption of bile acids and fat which exert a cathartic effect via an antiabsorptive/prosecretory action on sodium chloride transport in the unresected colon. There may also be a more basic defect in sodium chloride absorption. Water and sodium chloride absorption rates were measured during total gut perfusion with a balanced electrolyte solution (21) in eight patients with severe post resection diarrhea. Compared to controls, resection patients absorbed approximately $25 \%$ less water and sodium chloride, indicating that a loss of ileal and colonic ab. sorptive capacity for sodium chloride (rather than just the cathartic effect of unabsorbed bile acids or fat) may be an important factor in the production of diarrhea following DSBR.

Structural modifications in the mucosa following extensive intestinal resection or bypass are responsible for compensatory changes in nutrient $\mathrm{ab}$. sorption. Intestinal motility also contributes to this adaptation, the duration of postprandial interruption of the myoelectric complex rapidly increased after jejunal resection, gradually augmented after jejunal bypass and remained constant after ileal resection 


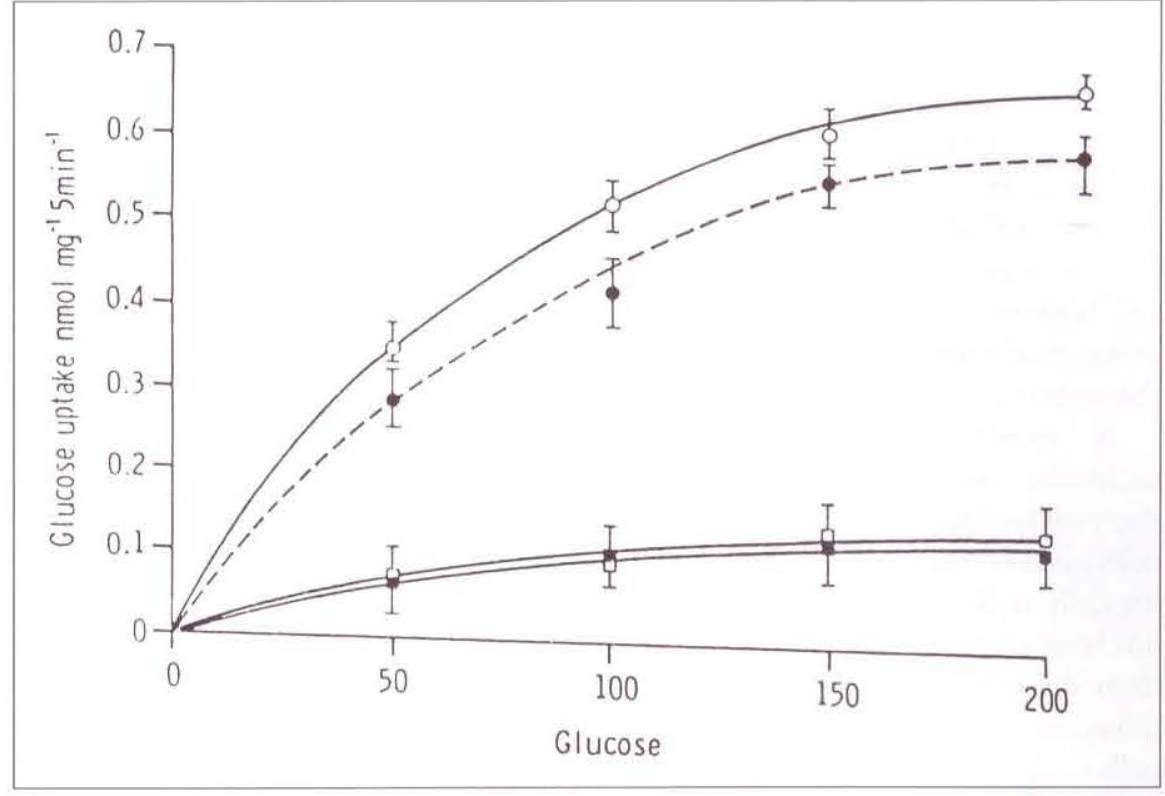

Figure 1) 3-0-methylghucose uptake against glucose concentration in buffer medium. $\square$ Control colon; Control jejunum; Jejunal autograft to colon without short bowel syndrome; Jejunal autograft to colon with short bowel syndrome. (Reproduced with permission from Banerjee et al, Dig Dis Sci 1990;35:340-8)

(22). This increase in duration of interruption of the myoelectric complex, spike bursts and the percentage of slow waves superimposed by spike bursts represents a decrease in muscular contractile activity intensity. Thus, nutrients may be in contact with the intestinal mucosa for a longer time, possibly contributing to the improved absorption in the remaining small bowel.

In intestinal segments left exposed to luminal contents after extensive small bowel resection, epithelial cell proliferation rate in the crypts and the rate of migration of these cells onto the villi increased, resulting in enlarged villi exhibiting increased absorptive capacity per unit length. Luminal factors such as nutrients and pancreaticobiliary secretions are important in cell proliferation maintenance. Circulating factors may also influence mucosal morphology and cell proliferation, eg, enteroglucagon and EGF have been implicated. The atrophic effect of luminal contents diversion can be counteracted by systemic growth factors released as part of the adaptive response (suggesting systemic growth factors are not dependent on a permissive effect of luminal contents [23]).

Most patients with short bowel syn- drome are managed with antidiarrheal agents as well as vitamin and nutrient supplements, including parenteral and enteral nutrition. Octreotide, a somatostatin analogue, improves the quality of life in some patients with short bowel syndrome (24).

Some patients may benefit from surgical therapy, including slowing of small intestinal transit with mucosal valves, antiperistaltic small intestine segments, colonic interposition, recirculating loops, intestinal electrical pacing and small bowel lengthening procedures. Growing new intestinal vestigated as a possible means of increasing intestinal absorptive area. Experimentally, intestinal defects patched with colon serosa, abdominal wall pedicle flaps and Dacron have become covered with functional neomucosa. Small intestinal function was maintained in the jejunocolonic graft after $80 \%$ small bowel resection in rats (25), with jejunal autograft to colon in short bowel syndrome animals transporting glucose at the same rate as control jejunum (Figure 1). The clinical importance of these interesting findings needs to be established.

Long chain triglycerides are effecmucosa (neomucosa) also has been in- tive in stimulating mucosal hyperplasia following massive resection of the small intestine. These beneficial effects may partly be related to the linoleic acid content of the diet; diets containing safflower oil (which is high in linoleic acid) are advantageous to the regeneration of intestinal mucosa following methotrexate-induced injury (26).

\section{EARLY DEVELOPMENT, ONTOGENY AND AGEING}

During postnatal development in the rat, brush border membrane (BBM) lactase activity decreases, macromolecular uptake ceases, BBM sucrase activity appears and alkaline phosphatase and maltase activities increase abruptly. Administration of cortisone to intact sucking animals induces precocious expression of sucrase activity and epithelial cell closure. Maternal milk contains a considerable amount of cortisone and circulating cortisone concentrations increase two to three days before this critical period of intestinal development. Luminal cortisone is absorbed and transported into the systemic circulation before inducing intestinal epithelial cell differentiation through the systemic route (27).

In the sucking period, intestinal maturation may also be influenced by thyroxine. The mature enterocyte of the weaned rat is unresponsive to insulin, but the precocious induction of BBM sucrase (and other BBM enzymes such as maltase, aminopeptidase and neutral lactase [28]) activity can be achieved with insulin. Secretin injected subcutaneously into young rats increases growth parameters such as protein and DNA content of the stomach and small intestine (29).

Lactase-phlorizin hydrolase is important for the nutrition of young animals. The activity of this enzyme is highest during the sucking period; after weaning activity usually falls to low adult levels. In both animals and humans this reduced enzyme activity is due to decreased enzyme synthesis. The core structure of microvillus membrane lactase-phlorizin hydrolase consists of both nitrogen-and oxygen-linked oligosaccharides. These remain constant during development, but the terminal 
sugars shift from being predominantly sialic acid during the sucking period, to fucose in adulthood (30).

The activities of intestinal sugar and amino acid transporters are matched to dietary levels of their carbohydrateand protein-derived substrates. Thus, the ratio of intestinal glucose to amino acid transporter increases with age in species where the ratio of dietary carbohydrate to protein also rises. This shift matches transporter activity to current dietary substrate levels and the high amino acid requirements of young growing animals (31).

In early infancy, the small intestine undergoes rapid growth and development associated with multiple alterations of intestinal structure and function. Clinical recovery precedes repair of intestinal structure and function abnormalities when refeeding infants suffering from protein-energy malnutrition. The intestinal damage may persist for a long time after clinical recovery. There may be a critical period for development of some intestinal transport functions and rechallenge with a diet fed for the first time in early life may differently influence feeding the diet initially in later life (32-34) (Figure 2).

Refeeding infant rabbits subjected to protein-energy malnutrition alters the small intestine. Refeeding stimulates rapid and complete recovery, as evidenced by jejunal and ileal mucosal mass restoration within four days, enhancement of epithelial renewal and enterocyte migration rate by day 7 , and complete return of the normal pattern of mucosal enzymes by day 14 (35). After $24 \mathrm{~h}$, continued starvation in the rat induces secretory hypersensitivity of the jejunum to many secretagogues and bacterial toxins, similar to hypersensitive small bowel responding to secretagogues and cholinergic neurotransmitters with a greatly enhanced secretory response seen in the rat ileum upon starvation (36).

Biotin is a water-soluble vitamin required for normal cellular functions and somatic growth. Using BBM vesicles obtained from Fisher 344 rats, the maximal rate of biotin transport increased between three and 12 months of age (37). In contrast, there

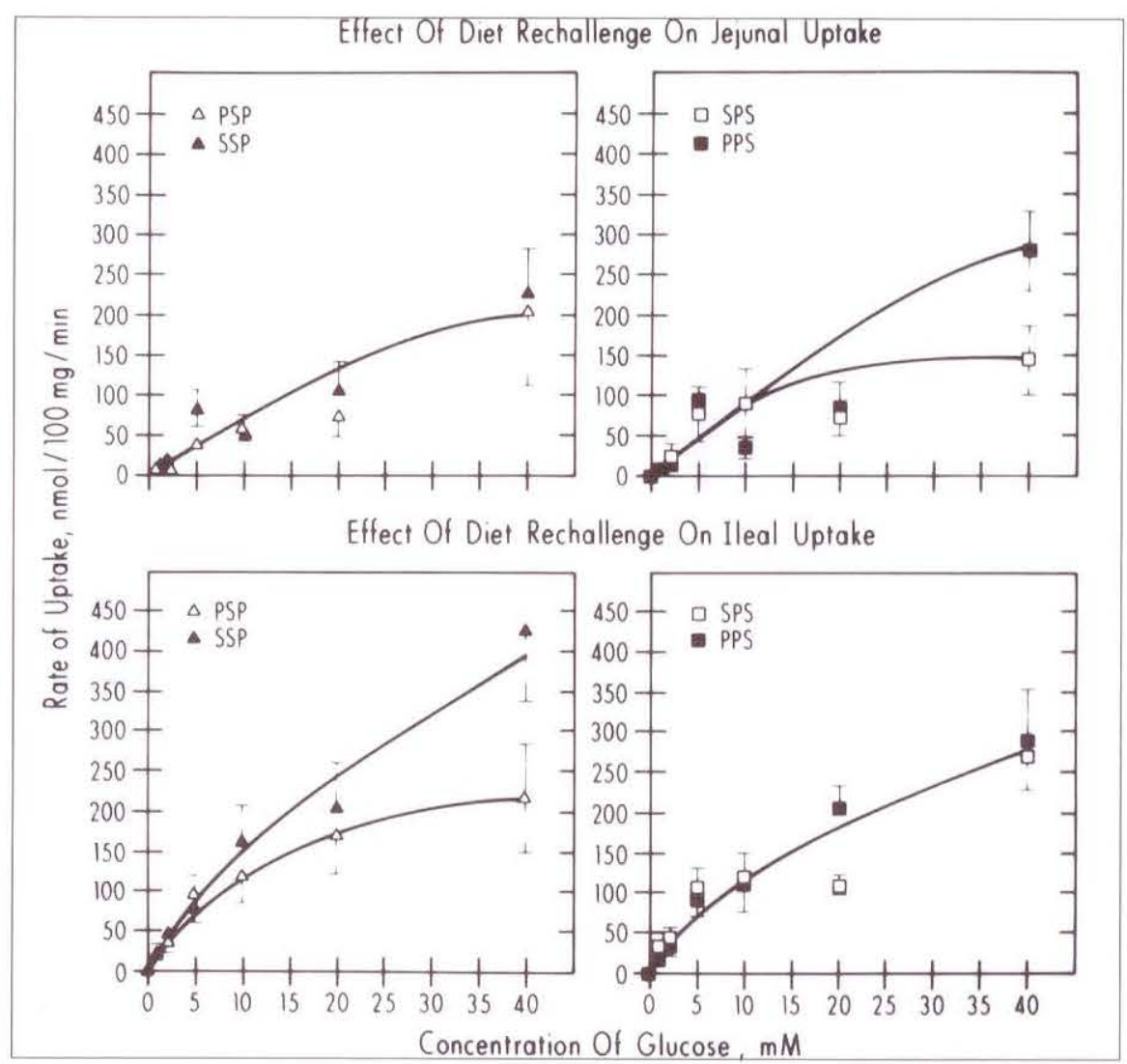

Figure 2) Effect of rechallenge with diets high in saturated or polyunsaturated fat content on jejunal and ileal uptake of glucose. The bulk phase was stirred at $600 \mathrm{rpm}$ to reduce the effective resistance of the intestinal unstirred water layer. P Polyunsaturated fatty acid diet; S Saturated fatty acid diet; PSP Feeding a polyunsaturated fatty acid diet followed in a cross-over manner by a saturated fatty acid diet followed by rechallenge with a polyunsaturated fatty acid diet; SSP Saturated fatty acid diet followed by a saturated fatty acid diet followed by a polyunsaturated fatty acid diet; SPS Saturated fatty acid diet followed by a polyunsaturated fatty acid diet followed by a saturated fatty acid diet; PPS Polyunsaturated fatty acid diet followed by a polyunsaturated fatty acid diet followed by a saturated fatty acid diet. (Reproduced with permission from Thomson et al, BBA 1989; 1001:302. 14)

was a reduction in the in vivo rate of active and passive absorption of glucose with ageing (38).

Digestive system disorders in the elderly have been reviewed (39). Crypt hyperplasia and hyperproliferation of the proximal small intestine occur in older rats without change in villus height or cell number. Diet restriction to $60 \%$ of the ad libitum feeding prolongs the lifespan of rats and prevents both duodenal hyperplasia and increase in ileal villus cell number (40).

\section{SALT AND WATER ABSORPTION}

Kinins are important mediators of intestinal secretion (41). A small increase in intraluminal pressure achieved by rat ileum distention inhibits net water and sodium absorption, and stimulates bicarbonate secretion by a neurally-mediated mechanism (42). In isolated hamster intestinal cells the amiloride-sensitive $\mathrm{Na}^{+} / \mathrm{H}^{+}$antiport is key in maintaining the intracellular $\mathrm{pH}$ neutral or slightly alkaline (43). The central nervous system also plays a role in intestinal function regulation, the intracerebroventricular injection of a gamma-aminobutyric acid agonist or a benzodiazepine agonist reduce ileal ion and water absorption in vivo, whereas injection of angiotensin $\mathrm{Il}$ or enkephalins enhance water absorption. Stimulating the dorsal motor nucleus of the vagus (which innervates the ileum) or the nucleus tractus solitarius reduces ileal water absorption by altering vagal efferent activity (44). 


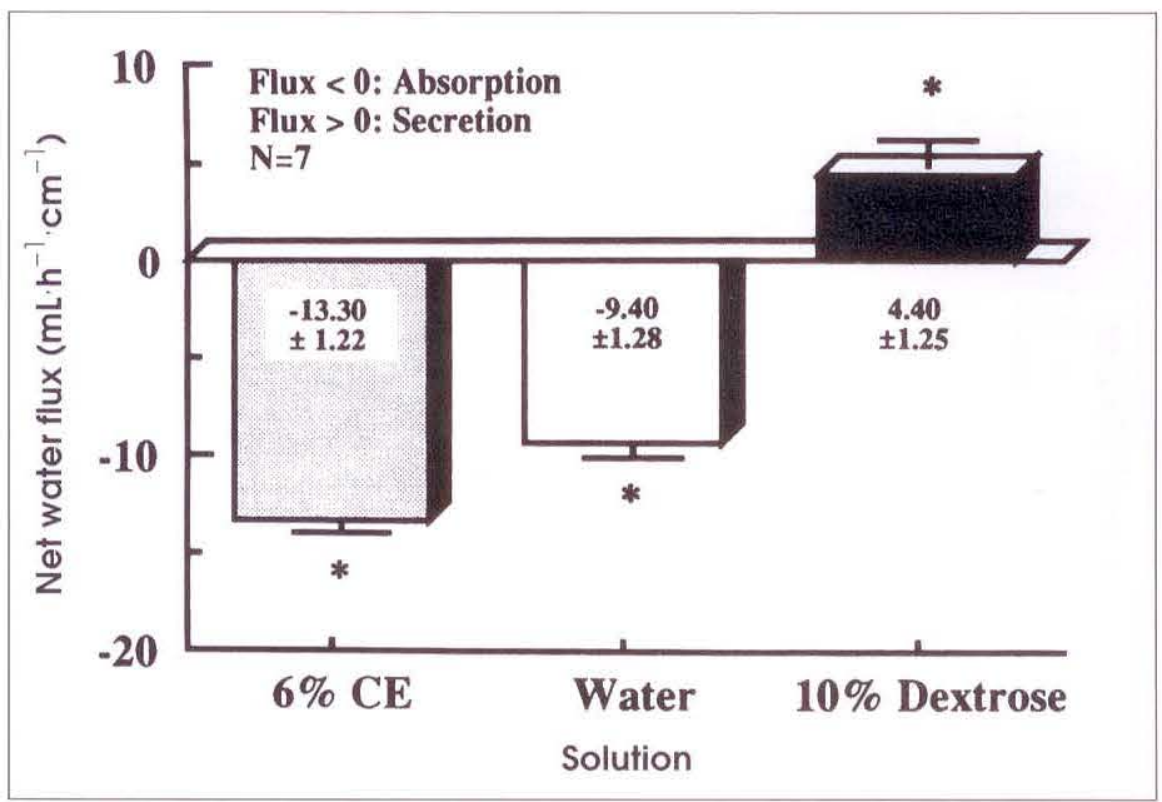

Figure 3) Net water flux during perfusion of different solutions. CE Carbohydrate-electrolyte. (Reproduced with permission from Gisolfi et al, Am J Physiol 1990;258:G216-G22)

Several $\alpha$-adrenergic receptors have been identified in the central nervous system. For example, clonidine binds to both $\alpha_{1}$ - and $\alpha_{2}$-adrenergic receptors (with a greater affinity for the $\alpha z$-receptors). Following intracerebroventricular but not intravenous injection of clonidine water absorption increases from the rat ileum; this effect is blocked by the $\alpha_{2}$-adrenergic receptor antagonist yohimbine (45), suggesting central $\alpha_{2}$-receptors regulate water absorption in the rat ileum and that this clonidineinduced increase in water absorption is not mediated by the sympathetic nerves innervating the intestine.

Volume regulation restores cell volume to normal by altering membrane transport after exposure to anisotonic media, leading to decreases or increases in cellular osmolites with osmotically obligated water. Changes in cell volume alter sodium, potassium and chloride fluxes. Ion transport activated during villus enterocyte swelling has been studied by ion substitution experiments, inhibitor and pharmacological sensitivity, and by direct measurement of the initial rate of ouabain-insensitive, bumetanide-sensitive ${ }^{86}$ rubidium influx (46). The increase in regulatory volume in guinea pig jejunal villus enterocytes apparently occurs due to hypertonic activation of sodium potassium chloride cotransport.

World Health Organization oral rehydration solution (ORS) containing L-alanine is superior to standard ORS in reducing symptoms and the need for fluid replacement in patients with diarrhea due to vibrio choleras or enterotoxigenic Escherichia coli (47). Alternate formulations of ORS include glucose or a glucose polymer, an amino acid or a peptide, or both. Alteratively, glucose may be replaced by staple food cereals, legumes or roots as a source of starch and protein. The inclusion of citrate, tartrate or betaine hydrochloride with bicarbonate in ORS formulation produces effervescence and improves solubility and palatability, but has no effect on water or solute absorption (48).

Perfusion studies performed in healthy volunteers have shown that net water absorption is greater with a carbohydrate-electrolyte solution than with water or a $10 \%$ dextrose solution (Figure 3 ). Indirectly measuring water absorption from deuterium oxide appearance does not appear to be a valid measure of net fluid movement from the duodenojejunum into the blood (49).

A scholarly review has been published on the structure and function of ion channels (50). Perfusion studies of human ileum in vivo have demonstrated that sodium and chloride are absorbed and bicarbonate is secreted against electrochemical gradients, and that there is a reciprocal movement of chloride and bicarbonate when sodium flux is zero. These observations suggest that the mechanism of sodium and chloride absorption in human ileum involves the simultaneous exchange of sodium for hydrogen and chloride for bicarbonate. Human ileal BBM vesicles have been prepared from organ donor intestine and have demonstrated $\mathrm{Na}^{+} / \mathrm{H}^{+}$exchanger and conductive transport pathways for sodium and hydrogen (51).

A second mechanism of sodium absorption is nutrient-coupled electrogenic absorption with which cDNA sequencing and cloning of the glucose cotransporter has been achieved (52). The third mechanism of sodium absorption is the nutrient-independent electrogenic system which is responsible for approximately half of the ileal sodium absorption. This mechanism is unaffected by amiloride (the pyrazine diuretic that blocks electrogenic sodium absorption in the distal colon). Phenamil is an amiloride analogue with a high affinity for sodium channels, but has minimal effect on $\mathrm{Na}^{+} / \mathrm{H}^{+}$exchange and does not block nutrientcoupled electrogenic sodium absorption or electrogenic chloride secretion. However, phenamil does block electrogenic sodium absorption in the terminal ileum of rabbits, possibly by affecting sodium channels in which the amiloride-binding site has been altered. Phenamil reversibly inhibits a specific conductance pathway accounting for the observed electrogenic sodium absorption (53).

Bicarbonate transport in rabbit ileum appears to be transcellular and is correlated with serosal bicarbonate and $\mathrm{pH}$ but not luminal changes in acidbase status. This ileal bicarbonate transport is inhibited by serosal chloride but is stimulated by luminal chloride (54). Glucocorticoids increase bicarbonate absorption and secretion, and adrenaline stimulates chloride-independent bicarbonate absorption. 
There may be discrete apical and basolateral transport mechanisms regulating bicarbonate transport, with secretion mediated by a basolateral transporter and an apical $\mathrm{Cl}^{-} / \mathrm{HCO}_{3}^{-}$exchange process. This $\mathrm{Cl}^{-} / \mathrm{HCO}_{3}^{-}$exchange mechanism accounts for approximately two-thirds of total chloride transport, with the remainder apparently occurring by a conductance pathway.

In BBM vesicles obtained from rat ileum, the $\mathrm{Na}^{+} / \mathrm{H}^{+}$exchanger undergoes maturational changes with a more than fourfold increase in the maximal transport rate from suckling to adult. The activity of $\mathrm{a} \mathrm{Cl}^{-} / \mathrm{HCO}_{3}{ }^{-}$exchanger declines from a high transport rate in the sucking period to a lower value in adults (55).

Pancreatic tumours associated with watery diarrhea, hypokalemia and achlorhydria in the Verner Morrison syndrome produce several related peptides derived from the same precursor molecule, preprovasoactive intestinal peptide. These three peptides, peptide histidine methionine (PHM), peptide histidine valine (PHV) and vasoactive intestinal peptide (VIP), inhibit absorption and stimulate secretion of water and electrolytes in the small intestine (56). VIPomas also secretes a larger form of PHM, peptide histidine valine-42 (PHV-42). Intravenous infusion of low doses of VIP, PHV and PHM in rats causes reduced absorption and increased secretion of fluid from the small intestine. PHV-42 appears the most potent, but the plasma concentration of VIP was approximately six times higher than the other two peptides and thus, VIP is apparently more important than PHM or PHV in mediating diarrhea in the Verner Morrison syndrome (57).

5-Hydroxytryptamine causes secretion of fluid and electrolytes into the intestinal lumen by decreasing coupled sodium chloride absorption and stimulating net chloride secretion. Ketanserin and cisapride are 5- $\mathrm{HT}_{2}$ antagonists, with cisapride also exhibiting weak $5-\mathrm{HT}_{3}$ antagonism. Since the 5-HT action stimulates chloride secretion, its administration is associated with larger potential difference and short circuit current across the intestinal wall. Cisapride inhibits the 5-HT-induced increases in the transintestinal potential difference, but over the same dose range it has no effect on fluid secretion induced by 5 HT. In contrast, ketanserin causes a dose-dependent reduction in 5-HT secretion at doses failing to influence the rise in potential difference (58) which suggests that different receptors are responsible for 5-HT effects on fluid secretion and electrical activity in the rat small intestine.

The location of the 5-HT receptor regulating intestinal ion transport is unknown, because specific 5-HT binding sites have not been detected on rat intestinal epithelial cell membranes. 5 HT may act indirectly via a cholinergic mechanism. The diarrhea of cholera occurs by a cyclic AMP-mediated active secretory mechanism but may also involve prostaglandin (PG) synthesis. $\mathrm{PGE}_{2}$ is an important intermediate in the transduction mechanism leading to 5-HT- induced intestinal secretion (59), possibly facilitating the entry of calcium into the cell. 5-HT may also be involved in the secretary mechanism of cholera toxin.

Enteric infection of New Zealand white rabbits with $E$ coli (a noninvasive enteroadherent organism colonizing both the mucosal surface and intestinal lumen) is an animal model of human enteropathogenic $E$ coli enteric disease. The diarrheal response may involve a decrease in sodium chloride absorption. However, changes in intestinal myoelectric activity precede the onset of clinical diarrhea and bacterial adherents to the intestinal mucosa may be important in eliciting the abnormal myoelectric responses $(60)$.

\section{BLOODFLOW AND INTESTINAL ISCHEMIA}

Mesenteric ischemia, enteral alimentation and infectious agents may contribute to the pathogenesis of neonatal necrotizing enterocolitis. Many factors have been implicated in necrotizing enterocolitis in infants and it has been proposed that this represents a manifestation of ischemia and reperfusion.

Developing young piglets are at greater risk than older animals for intestine tissue hypoxia induced by arterial hemorrhage (61). The neonatal intestine has a limited capacity to maintain oxygen uptake during reductions in perfusion pressure, arterial hypoxia, hemorrhage or the combined stresses of hypoxia and feeding because of the decreased collateral perfusion between adjacent gut segments after occlusion of a superior mesenteric artery branch (62). Luminal perfusion with formula results in higher clearances of ${ }^{51}$ chromium EDTA in younger animals, indicating that the neonatal intestine is more vulnerable to mucosal injury induced by ischemia and reperfusion in the presence of formula than the intestine of older animals (63).

Reductions in intestinal bloodflow followed by ischemia and reperfusion of oxygenated blood result in mucosal damage which may be due to formation of oxygen-free radicals, extravasation of polymorphonuclear leukocytes and release of local mediators such as myeloperoxidase enzymes.

Ischemia alone does not change cyclooxygenase products, but reperfusion following ischemia increases mucosal prostaglandins including LTB$_{4}$ and 12-HETE (64). Xanthine oxidase inhibition, neutropenia or prevention of granulocyte adherence to microvascular endothelium largely prevents the increased microvascular permeability induced by ischemia/ reperfusion. Either hydrogen peroxide or radical species derived from the interaction of superoxide and hydrogen peroxide with iron elicit ischemia/ reperfusion-induced granulocyte infiltration in the intestine (65).

Hypoxanthine is converted to xanthine, with the release of a free radical superoxide anion, in the presence of xanthine oxidase and with the reintroduction of oxygenated blood. These free radicals are toxic to cell membranes, the cytosol and nuclei, and are normally dismutated to hydrogen peroxide and oxygen in a reaction which is controlled by the enzyme superoxide dismutase. Human superoxide dismutase given to weanling New Zealand rabbits reduces mucosal damage when given intraluminally or 
parenterally (66); the clinical significance of this observation needs to be extended to studies in humans.

Another explanation for the greater susceptibility of younger animals to intestinal ischemia may be that oxygen extraction does not increase to compensate for the reduced flow, resulting in less oxygen uptake. When aminophylline is administered to newborn lambs, there is an increase in intestinal bloodflow and splanchnic oxygen consumption (67); these effects might reduce the reserve available for maintenance of tissue oxygen supply under conditions of feeding, hypoxemia and hypotension. Aminophylline could increase ischemic injury to the gastrointestinal tract under these circumstances and might facilitate necrotizing enterocolitis development.

The mechanisms for increased intestinal bloodflow after a meal may include hormones, tissue metabolism, gastrointestinal peptides, histamine, prostaglandins, tissue osmolality and local nerves. The vasodilatory response to food occurs in the upper intestine in response to exposure to chyme and, in particular, after exposure to micellar lipid. Bile-oleate-induced intestinal hyperemia is inhibited by local anesthetics but not extrinsic denervation of the intestine, suggesting that local neurogenic mechanisms may be involved. Chemosensitive primary afferent nerves are involved in intestinal bloodflow regulation while the neurotoxin capsaicin depletes afferent Cfibres of their peptide transmitters. Using capsaicin in young and adult rats, pulsed Doppler measured intestinal bloodflow appeared to involve primary afferent nerve fibres of the intestine that release VIP (68).

Endogenous intestinal prostanoids may also play a role in bloodflow and oxygen uptake regulation during nutrient absorption. Production of $\mathrm{PGE}_{2}$ and $\mathrm{PGI}_{2}$ (vasodilators), and PGF2" and thromboxane (TX)A $A_{2}$ (vasoconstrictors) increase during nutrient absorption. The addition of arachidonate to food attenuates $\mathrm{PGI}_{2}$ and $\mathrm{PGE}_{2}$ production and enhances $\mathrm{TXA}_{2}$ and $\mathrm{PGF}_{2}$ " release attenuating food-induced jejunal hyperemia (69).
Adenosine may also play a role in intestinal pressure-flow autoregulation. Drugs that enhance adenosine-induced vasodilation similarly affect foodinduced hyperemia which is also associated with increased venous adenosine concentrations, suggesting that adenosine participates in postprandial jejunal hyperemia (70).

The endothelium is the source of factors that modulate vessel tone and mediate relaxation or constriction of vascular smooth muscle cells induced by hormones or neurotransmitters. Endothelin has been isolated from porcine aortic endothelial cells and stimulates the release of prostacyclin from rat mesenteric arteries (71), but its role in ischemia and reperfusion needs to be established.

The enteral or intravenous administration of metronidazole or gentamycin to rats subjected to superior mesenteric artery ischemia improves survival time (72). The mechanism of this beneficial effect is unknown but likely is more than an antibacterial effect. Allopurinol is a xanthine oxidase inhibitor which may reduce ischemia severity when given prior to or after induction of ischemic damage. Survival of animals from an occlusion is most enhanced by giving allopurinol by mouth before the ischemic event. The beneficial effect may not be due to xanthine oxidase blockage, but rather to the allopurinol and oxypurinol levels in the intestinal wall (73).

The most frequent causes of ischemic colitis and enteritis are occlusion of the main mesenteric arteries or veins, vasculitis or a nonocclusive splanchnic spasm. Three patients have been reported with lymphocytic infiltration of the vein with a mixture of $\mathrm{T}$ and $\mathrm{B}$ lymphocytes (74). The intestinal necrosis was not associated with systemic vasculitis and there was no evidence of recurrence necessitating reoperation.

Duplex ultrasound scanning is useful to investigate patients with cerebrovascular disease or occlusive disease of the extremities. This technique can measure resting mesenteric bloodflow and detect mesenteric vascular responses to food, glucagon, intravenous vasopressin (75) or in pathological conditions such as acute or chronic mesenteric ischemia, portal hypertension or the dumping syndrome. The widespread clinical application of this technique is worthy of investigation.

\section{BRUSH BORDER MEMBRANES AND ENTEROCYTES}

The structure and function of the BBM have been 'revisited' (76). Luminal nutrition (the direct effect of food within the lumen on the intestinal mucosa) maintains normal small intestinal structure and causes adaptation to altered luminal conditions (77). Lipid composition of the BBM, the enterocyte microsomes and their transport and enzymatic function may adapt to the type of fatty acid or the amount of cholesterol in the diet (78-84). Supplementation of an elemental diet with essential fatty acids increases intestinal mucosal weight above that of animals fed either the elemental diet alone or normal chow. Triglycerides, regardless of essential fatty acid content, are trophic to the rat small intestinal mucosa (85).

Glutamine rather than glucose is the major substrate for energy production in the small intestinal epithelial cells. In rat and human intestine there is a sodium-dependent and a sodium-independent carrier-mediated transport process for glutamine. Insulin treatment of the diabetic rat reduces the enhanced maximal transport rate for glutamine absorption (86).

Commercially available amino acid solutions, (used in formulation of parenteral nutrient mixtures) do not contain glutamine; most enteral formulas include only small quantities or are devoid of this amino acid. The observation that glutamine concentrations are low in stress states, coupled with repeated documentation that intestinal mucosa atrophy occurs during administration of parenteral nutrition, raises the possibility that a relative glutamine deficiency may develop during critical illnesses. Glutamineenriched nutrition protects against atrophy of the intestinal mucosa and improves nitrogen retention during intravenous feeding in rats (87). 
The frequency of contraction in dog intestine villi has been measured using videomicroscopy (88). Plasma volume expansion increases villus motility but decreases absorption of water and lauric acid, suggesting that while villus motility may agitate the intestinal unstirred water layers, the mixing is not directly associated with altered nutrient transport.

An acidic microclimate has been described adjacent to the BBM and $\mathrm{pH}$ sensitive liquid ion-exchanger microelectrodes have demonstrated a region of low $\mathrm{pH}$ in the upper parts of the rat small intestinal villi, with a more alkaline $\mathrm{pH}$ at the villus base (89). This acid microclimate tends to favour fatty acid uptake from the upper portion of the villus due to the greater membrane permeability of the protonated species.

While it has been widely suggested that the origin of secretion in the small intestine lies in the crypts, this view has been challenged by an in vitro study using intracellular microelectrodes (90). Under basal conditions, villus membrane potentials exceed those in the crypt and the apical membrane potentials are increased by secretagogues. Because a chloride-dependent depolarization of apical membrane potentials occurs in both villi and crypts, net secretion in the small bowel is probably not confined to the crypts and may also occur from villus epithelium.

Phytohemagglutinin is a lectin contained in uncooked kidney beans which binds to the microvilli of villus but not crypt cells in animals. Repeated ingestion of raw beans damages these villus absorptive cells, with vesiculation and shortening of the microvilli resulting in impaired nutrition, growth inhibition and even death of the animal. Other lectins, including concanavalin $\mathrm{A}$ and wheat germ agglutinin, may also injure the mammalian intestine although this damage appears to be limited and reversible. The repair of microvilli following phytohemagglutinin is due to intrinsic reparative processes rather than accelerated replacement of damaged cells (91).

Enterocytes adhere to the basement membrane until they are released into the lumen, with this membrane providing a substratum for cell adhesion. Components of the intestinal basement membrane are synthesized by both mesenchymal-and entodermal-derived cells (ie, enterocytes) (92). Statin is a nuclear protein present in differentiated, nonproliferating villus enterocytes (93). The cessation of proliferation observed when crypt cells migrate to the villus is associated closely with the gradual appearance of statin in the nucleus; it is unknown whether the amount or position of appearance of statin changes in hyper- or hypoproliferative intestinal disorders.

\section{DIABETES MELLITUS}

The topic of diabetic enteropathy has been reviewed (94). Diabetes mellitus in experimental animals enhances intestinal nutrient absorption and produces hyperpolarization of the BBM with an increase of the potential difference across the BBM and a reduced conductance of sodium (95). Uptake into diabetic BBM vesicles demonstrates an increased initial glucose uptake rate. The lower sodium permeability in diabetes may enhance the electrical and chemical driving force for active sodium-dependent uptake of glucose by reducing glucose-independent movement of sodium across the BBM. The upper portion of the villus, where nutrient transport occurs, may expand in diabetes (96).

After the development of diabetes in rats, the activities of pancreatic lipase and trypsin and the levels of lipase and trypsinogen mRNA increased (97), suggesting that the pretranslational control of pancreatic lipase and trypsinogen is stimulated in diabetes which results in high levels of these enzymes.

High glucose concentrations have been shown to induce DNA damage, hamper replication and accelerate death in cultured human endothelial cells. The percentage of doublestranded DNA unwinding in brain, liver and intestinal epithelium of diabetic rats is reduced compared to control animals; insulin treatment normalizes this reduced rate of DNA unwinding in liver and intestine (98).
Thus, chronic, uncontrolled hyperglycemia can alter chromatin structure in vivo. The implication of this observation to humans with diabetes mellitus needs to be established.

Gastrointestinal symptoms are common in diabetic patients and occasionally occur in the absence of structural abnormalities. If extraintestinal manifestations of vascular or neuropathic complications are evident, the symptoms may be directly attributed to diabetes (abnormalities in gastrointestinal motility are the presumed mechanism). In nondiabetic patients, these symptoms might be attributed to the 'irritable bowel syndrome'.

Psychological factors may also contribute to irritable bowel syndrome; the leading associated diagnostic criteria include depression, hysteria and anxiety. However, the symptoms of psychologic distress may only influence which individuals with the syndrome's symptoms will consult a doctor and thereby become a 'patient' $(99,100)$.

In diabetic patients, upper gastrointestinal tract symptoms, altered bowel habits and abdominal discomfort are more likely associated with 'psychiatric illness' (affective and anxiety disorders determined with a structured interview and standard diag. nostic criteria) rather than being associated with peripheral neuropathy (established using nerve conduction studies and objective tests of autonomic function) (101).

\section{GASTROINTESTINAL PEPTIDES}

Somatostatin influences gastric and pancreatic secretion, intestinal absorption, gastrointestinal motility and epithelial cell proliferation. In infants, milk is a possible source of gastric luminal somatostatin. Somatostatin is stable in the gastric lumen and milk protects this cyclic tetradecapeptide from intestinal luminal proteolysis (102).

Epidermal growth factor is present in amniotic fluid and is transported across epithelium of fetal rats by an endocytotic process (103) (possibly because receptors for epidermal growth factor are present on fetal intestinal 
BBM). Cell surface epidermal growth factor receptors have been identified on isolated cells from intestinal crypts, villi and basolateral membranes of enterocytes (104). Thus, although epidermal growth factor is secreted into the intestinal lumen by duodenal Brunner's glands, crypt Paneth cells and goblet cells, its growth and maturational effects probably result from a specific interaction between it and its receptor on the basolateral membrane.

\section{VITAMINS AND MINERALS}

Dietary folates occur mainly as pteroylmonoglutamates (PteGlun which undergo hydrolysis before the end product, pteroylpolyglutamate (PteGlu), is absorbed. Acute exposure of jejunal vesicles to ethanol or chronic feeding of ethanol decreases PteGlu hydrolase, but has no effect on PteGlu transport (105).

BBM lipid composition is influential for determining calcium uptake, but fluidity does not necessarily correlate with calcium uptake (106). Intestinal calcium absorption is mediated by a transcellular active process that depends entirely on vitamin $D$ and a paracellular pathway. Calcium transport is proportional to the intestinal concentration of calbindin, a calcium-binding protein. Vitamin D deficiency leads to calbindin deficiency, but also enhances calcium entry across the BBM, promotes intracellular calcium binding, and stimulates calcium extrusion across the basolateral membrane as a result of Ca-Mg-ATPase activation. Theophylline inhibits transcellular intestinal calcium transport by blocking calcium binding to calbindin (107). Mucosal addition of quinacrine also inhibits the mucosal to serosal calcium flux across the duodenum (108) which suggests that acidic lysosomal vesicles are important in calcium transcellular transport.

BBM vesicles were obtained from the intestine of three cadaveric renal transplant donors; calcium uptake was sodium-independent and electroneutral with a mediated and a nonmediated component. The affinity constant values of the mediated component increased aborally and the maximal transport rate was highest in the duodenum (followed by, in descending order, the ileum, terminal ileum and jejunum). The nonmediated component was greatest in the duodenum and also decreased aborally (109).

There is controversy whether magnesium and calcium share a common transport mechanism. In rat terminal ileum, magnesium is absorbed in vitro at least partially by a cellular, vitamin D3-insensitive process different from the calcium transport mechanism (110).

The intestine is a major target tissue for 1,25-dihydroxyvitamin $\quad D_{3}$ $\left(1,25(\mathrm{OH})_{2} \mathrm{D}_{3}\right)$, which stimulates transepithelial flux of calcium and phosphate, and regulates the intestinal production of calbindin. The overall effect of $1,25(\mathrm{OH})_{2} \mathrm{D}_{3}$ on intestinal calcium and phosphorous absorption is increased cell-mediated active mucosal to serosal transport and paracellular diffusional serosal to mucosal movement (111). The major quantitative effect of vitamin $D$ is on the rate of calcium intracellular flux. C-24 oxidation and side-chain cleavage of $1,24(\mathrm{OH})_{2} \mathrm{D}_{3}$ play an important role in degradation of vitamin D metabolites in the kidney, bone and intestine (112); this 1,25. hydroxy $D_{3}$-inducible degradation of vitamin $\mathrm{D}$ metabolites in the intestine can be prevented by transcriptional inhibitors such as actinomycin D and $\alpha$ amanitin which suggests that mRNA synthesis is required for the induction process.

A sodium-dependent inorganic phosphate transport system has been identified in the intestinal BBM. A reduction in the dietary supply of inorganic phosphate induces a stimulation of this transporter and results in an increased maximal transport rate and a reduced affinity constant, with the change in the inorganic phosphate transport correlated with an increase in the circulating level of $1,25-(\mathrm{OH})_{2} \mathrm{D}_{3}$ (113).

Iron uptake into the intestinal mucosa occurs by at least two pathways; one is facilitated by free fatty acids, while the second (and quantitatively more important) requires metabolically active cells, is sensitive to metabolic inhibitors, exhibits saturation kinetics and has an adaptive response to changes in iron requirements. The iron uptake process may also be dependent on the BBM potential (114).

Although the iron content of milk is low, human infants consuming maternal milk maintain adequate iron status because of the high bioavailability of iron from human milk. Iron-binding proteins may facilitate iron uptake by the small intestine. In rat and rabbit milk, transferrin is the major iron-binding protein, whereas it is lactoferrin in human, monkey and bovine milk. Transferrin receptors are present on the $\mathrm{BBM}$ of sucking rats. Bovine lactoferrin competitively inhibits the binding of rat transferrin to the BBM vesicles (115).

Endoscopic biopsy specimens of the duodenum have been obtained and analyzed for transferrin L-ferritin and $\mathrm{H}$-ferritin (116) in normal subjects and those with idiopathic hemochromatosis. The L-ferritin functions primarily as an intracellular iron storage protein, whereas $\mathrm{H}$-ferritin may play a role in immunosuppression and myelopoietic regulation.

There is greater absorption of hemeiron compared with nonheme-iron in normal subjects and in idiopathic hemochromatosis (although idiopathic hemochromatosis patients demonstrate a much greater absorption of both heme- and nonheme-iron). However, mucosal transferrin levels do not show a difference between normal subjects or those with depleted iron stores. In idiopathic hemochromatosis nonheme-iron absorption occurs at levels of serum ferritin much higher than those found in normal subjects, yet the mucosal ferritin levels are much lower in idiopathic hemochromatosis patients than in control subjects and appear to be appropriate for the degree of nonheme-iron absorbed.

The binding of apotransferrin to basolateral membranes increases in iron deficiency. When iron absorption is increased following acute hemolysis (without a change in body stores), there is no change in transferrin receptor number (117). Thus, mucosal transferrin does not appear to regulate 
significantly iron absorption in normal subjects. The mucosal levels of $\mathrm{L}$-ferritin in idiopathic hemochromatosis patients are appropriate for the degree of iron absorption, but are much lower relative to the elevated serum levels of ferritin.

It remains uncertain whether the mucosal $\mathrm{L}$-ferritin has a regulatory role in idiopathic hemochromatosis. There appears to be normal regulation of the transferrin and ferritin receptors in the liver in idiopathic hemochromatosis, but the villus epithelial cells express receptor in the basolateral, subnuclear region of the enterocyte in untreated idiopathic hemochromatosis and normal subjects (118). In patients with secondary iron overload, receptor staining is absent in villus epithelial cells but intense staining for the transferrin receptor remains in the crypts suggesting that a failure of downregulation of the villus enterocyte transferrin receptor in idiopathic hemochromatosis may reflect the presence of a regulatory defect associated with the inability to control iron ab. sorption.

\section{REFERENCES}

1. Kikuchi K, Kikuchi T, Miwa T, Ghishan FK. Effect of dietary polyamines and $\alpha$-difluoromethylornithine on regulation of intestinal $\mathrm{Na}^{+} \mathrm{H}^{+}$exchanger. J Dev Physiol 1989;12:163-7.

2. Ginty DD, Marlowe M, Pekala PH, Seidel ER. Multiple pathways for the regulation of ornithine decarboxylase in intestinal epithelial cells. Am J Physiol 1990;258:G454-60.

3. Iwami K, Wang J-Y, Jain R, et al. Intestinal ornithine decarboxylase: Half-life and regulation by putrescine. Am J Physiol 1990;258:G308-15.

4. Osborne DL, Seidel ER. Gastrointestinal luminal polyamines: Cellular accumulation and enterohepatic circulation. Am J Physiol 1990;258:G576-84.

5. Thompson JS, Laughlin K. Relationship of jejunostomy and urine polyamine content to refeeding and intestinal structure and function. JPEN 1989;13:13-7.

6. Buts J-P, Theys S, De Keyser N, Dive $\mathrm{C}$. Changes in serum and intestinal diamine oxidase (DAO) activity after proximal enterectomy in rats. Correlation of DAO activity with
Zinc reduces the affinity of glucose for its carrier, but does not influence sodium binding to the transporter (119). This effect of zinc on glucose uptake is not due to dissipation of the sodium gradient or an effect on glucose efflux from BBM vesicles. Poor intake of zinc and an absorption defect have been proposed as the major causes of zinc deficiency. Intestinal perfusion studies performed in healthy humans have demonstrated that the jejunum has the highest rate of zinc absorption, followed by the duodenum and the ileum (120). While the uptake of zinc is concentration-dependent, interactions between absorption of zinc and other solutes suggests that the transport process may also be carrier-mediated. In contrast, the intestinal absorption of zinc is stimulated by addition of glucose to the perfusate (increasing zinc concentration in the perfusate results in decreased absorption of sodium and water).

Vitamin B12 absorption, malabsorption (121) and binding proteins have been reviewed (122). Using a panel of monoclonal antibodies against human

mucosal mass parameters. Dig Dis Sci 1989;34:1393-8.

7. D'Agostino L, Daniele B, Pignata S, Greco L, Mazzacca G. Postheparin plasma diamine oxidase in subjects with small bowel disease. Digestion 1988:41:46-54.

8. Koyama S, Podlosky DK. Differential expression of transforming growth factors alpha and beta in rat intestinal epithelial cells. J Clin Invest 1989:83:1768-73.

9. Barnard JA, Beauchamp RD, Coffey RJ, Moses HL. Regulation of intestinal epithelial cell growth by transforming growth factor type beta. Proc Natl Acad Sci 1989;86:1578-82.

10. Lavagna C, Douzinas E, Nano J-L, Rampal. Purification and biological properties of an epithelial intestinal cell growth inhibitor from a human small intestine. Biochim Biophys Acta 1990;1051:259-65.

11. Tutton PJM, Barkla DH. Effect of an inhibitor of noradrenaline uptake, desipramine, on cell proliferation in the intestinal crypt epithelium. Virchows Archiv [B] 1989;57:349-52.

12. Sakata T. Stimulatory effect of short-chain fatty acids on epithelial cell proliferation of isolated and intrinsic factor, cobalamin binding and receptor functions occur at separate sites on intrinsic factor (123). Vitamin $B_{12}$ is bound to intrinsic factor and the intrinsic factor vitamin $\mathrm{B}_{12}$ complex binds to receptors in the ileum located in the intermicrovillus pits of the epithelium. Several hours later vitamin $B_{12}$ appears in the portal circulation bound to transcobalamin II. Caco-2 cells bind and internalize intrinsic factor vitamin $\mathrm{B}_{12}$ complexes across the apical membrane synthesize and secrete a protein similar to transcobalamin II (this protein is secreted from the cell's basolateral side). This data provides evidence for the transcellular transport of cobalamin across these polarized monolayers (124). Chloroquine, an inhibitor of the vesicular and lysosomal proton pump, delays transfer of cobalamin from intrinsic factor to transcobalamin II (125).

Pantothenic acid is a water-soluble B-complex vitamin which is absorbed by a saturable, sodium-dependent, energy-requiring transport mechanism in mice (126).

denervated jejunal segment of the rat. Scand J Gastroenterol 1989;24:886-90.

13. Meyer JH, Doty JE. GI transit and absorption of solid food: Multiple effects of guar. Am J Clin Nutr 1988;48:267-73.

14. Hosoda N, Nishi M, Nakagawa M, Hiramatsu Y, Kiaki K, Yamamoto M. Structural and functional alterations in the gut of parenterally or enterally fed rats. J Surg Res 1989;47:129-33.

15. Fisher RL. Malabsorption and Nutritional Status and Support. Gastroenterology Clinics of North America. Philadelphia, London, Toronto, Montreal, Sydney, Tokyo: WB Saunders Co, Harcourt Brace Jovanovich Inc, 1989;18(3).

16. Brasitus TA, Sitrin MD, Intestinal malabsorption syndromes. Annu Rev Med 1990;41:339-47.

17. Singer P, Askanazi J. Total parenteral nutrition. Curr Opin Gastroenterol 1990;6:204-11.

18. Katz DP, Kvetan V, Askanazi J. Enteral nutrition: Potential role in regulating immune function. Curr Opin Gastroenterol 1990;6:199-203.

19. Bounous $\mathrm{G}$. Elemental diets in the prophylaxis and therapy for intestinal lesions: An update. Surgery 
$1989 ; 105: 571-5$

20. Vazquez CM, Molina MT, Ilundain A. Role of rat large intestine in reducing diarrhea after $50 \%$ or $80 \%$ distal small bowel resection. Dig Dis $\mathrm{Sci}$ 1989;34:1713-9.

21. Arrambide KA, Santa Ana CA, Schiller LR, Little KH, Santangelo WC, Fordtran JS. Loss of absorptive capacity for sodium chloride as a cause of diarrhea following partial left and right colon resection. Dig Dis Sci 1989;34:193-201.

22. Wittmann T, Crenner F, Koenig M, Grenier JF. Adaptive changes in postprandial motility after intestinal resection and bypass. Electromyographic study in rats. Dig Dis Sci 1988;33:1370-6.

23. Albert V, Young GP, Morton CL, Robinson P, Bhathal PS. Systemic factors are trophic in bypassed rat small intestine in the absence of luminal contents. Gut 1990;31:959. (Lett)

24. Nightingale JMD, Walker ER, Burnham WR, Farthing MJG, Lennard-Jones JE. Octreotide (a somatostatin analogue) improves the quality of life in some patients with a short intestine. Aliment Pharmacol Therap 1989;3:367-73.

25. Bannerjee AK, Chadwick SJD, Peters T]. Adaptation of jejunal to colonic mucosal autografts in experimentally induced short bowel syndrome. Dig Dis Sci 1990;35:340-8.

26. Vanderhoof JA, Park JHY, Mohammadpour H, Blackwood D. Effects of dietary lipids on recovery from mucosal injury. Gastroenterology 1990;98:1226-31

27. Yeh K-Y, Yeh M, Holt PR. Induction of intestinal differentiation by systemic and not by luminal corticosterone in adrenalectomized rat pups. Endocrinology 1989;124:1898-904.

28. Buts J-P, De Keyser N, Kolanowski J, Van Hoof F. Hormonal regulation of the rat small intestine: Responsiveness of villus and crypt cells to insulin during the suckling period and unresponsiveness after weaning. Pediatric Res 1990;27:161-4.

29. Pollack PF, Wood JG, Solomon T. Effect of secretin on growth of stomach, small intestine and pancreas of developing rats. Dig Dis Sci 1990;35:749-58.

30. Büller HA, Rings EHH, Pajkrt D, et al. Glycosylation of lactase-phlorizin hydrolase in rat small intestine during development. Gastroenterology 1990;98:667-75.

31. Toloza EM, Diamond JM. Ontogenetic development of nutrient transporters in bullfrog intestine. Am J Physiol 1990;258:G760-9.

32. Thomson ABR, Keelan M, Garg ML,
Clandinin MT. Evidence for critical period programming of intestinal transport function: Variations in the dietary ratio of polyunsaturated to saturated fatty acids alters ontogeny of the rat intestine. Biochim Biophys Acta 1989;1001:302-15.

33. Thomson ABR, Keelan M. Rechallenge following an early life exposure to a high cholesterol diet enhances diet-associated alterations in intestinal permeability. J Pediatr Gastroenterol Nutr 1989;8:98-104.

34. Keelan M, Thomson ABR, Garg ML, Clandinin MT. Critical period programming of intestinal glucose transport via alterations in dietary fatty acid composition. Can J Physiol Pharmacol 1990;68:642-5.

35. Butzner JD, Gall DG. Impact of refeeding on intestinal development and function in infant rabbits subjected to protein-energy malnutrition. Pediatr Res 1990:27:245-51.

36. Young A, Levin RJ. Diarrhoea of famine and malnutrition Investigations using a rat model. II. Ileal hypersecretion induced by starvation. Gut 1990;31:162-9.

37. Said HM, Horne DW, Mock DM. Effect of aging on intestinal biotin transport in the rat. Exp Gerontol 1990;25:67-73.

38. Vinardell MP, Age differences on ileal glucose absorption in rats. Mech Ageing Dev 1990;51:243-7.

39. Schamburek RD, Farrar JT. Disorders of the digestive system in the elderly. N Engl J Med 1990;327:438-42.

40. Heller TD, Holt PR, Richardson A. Food restriction retards age-related histological changes in rat small intestine. Gastroenterology 1990;98:387-91

41. Gaginella TS, Kachur JF. Kinins as mediators of intestinal secretion. Am J Physiol 1989;256:G1-15.

42. Harris MS, Ramaswamy K, Kennedy JG. Induction of neurally mediated $\mathrm{NaHCO}_{3}$ secretion by luminal distension in rat ileum. Am J Physiol 1989;257:G191-7.

43. Goré J, Hoinard C. $\mathrm{Na}^{+} / \mathrm{H}^{+}$exchange in isolated hamster enterocytes. Gastroenterology 1989;97:882-7.

44. Martin K, Kong TH, Renehan W, et al. Identification and function of brain stem neurons regulating rat ileal water absorption. Am J Physiol 1989;257:G266-73.

45. Fogel R, Kong TH, Dong WH, Pfeiffer M, Michelson G. Regulation of rat ileal water absorption by central $\alpha_{2}$ adrenergic receptors. Dig Dis Sci 1990;35:737-42.

46. MacLeod RJ, Hamilton JR. Regulatory volume increase in mammalian jejunal villus cells is due to bumetanidesensitive $\mathrm{NaKCl}_{2}$ cotransport. Am ] Physiol 1990;258:G665-74.

47. Patra FC, Sack DA, Islam A, Alam AN, Mazumder RN. Oral rehydration formula containing alanine and glucose for treatment of diarrhoea: A controlled trial. Br Med J 1989;298:1353-6.

48. Leiper JB, Maughan RJ. Absorption of water and solute from glucoseelectrolyte solutions in the human jejunum: Effect of citrate or betaine. Scand J Gastroenterol 1989;24:1089-94.

49. Gisolfi CG, Summers RW, Schedl HP, Bleiler TL, Oppliger RA. Human intestinal water absorption: Direct versus indirect measurements. Am J Physiol 1990;258:G216-22.

50. Krueger BK. Toward an understanding of structure and function of ion channels. FASEB J 1989;3:1906-14.

51. Ramaswamy K, Harig JM, Kleinman JG, Harris MS, Barry JA. Sodiumproton exchange in human ileal brush-border membrane vesicles, Biochim Biop Acta 1989;981:193-9.

52. Hediger MA, Coady MJ, Ikeda TS, Wright EM. Expression cloning and cDNA sequencing of the $\mathrm{Na}^{+}$/glucose co-transporter. Nature 1987;330:379-81.

53. Sellin JH, Oyarzabal H, Cragoe EJ, Potter GD. Phenamil inhibits electrogenic sodium absorption in rabbit ileum. Gastroenterology 1989;96:997-1003.

54. Sellin JH, Desoignie R. Regulation of bicarbonate transport in rabbit ileum: $\mathrm{pH}$ stat studies. Am J Physiol 1989;257:G607-15.

55. Riedel BD, Ghishan FK. Maturation of chloride-bicarbonate exchange in rat ileal brush border membrane vesicles. Pediatr Res 1989;25:189-93.

56. Spokes RA, Yiangou Y, Chrysanthou B], Bowles MPS, Bloom SR. Effects of preprovasoactive intestinal polypeptide-derived peptides on net fluid flux in small intestine of anesthetized rats. Gastroenterology 1989:96:327-30.

57. Calam J, Yiangou Y, Nikou GC, et al. Effects of preprovasoactive intestinal polypeptide-derived peptides on ileal output. Gastroenterology 1990;98:505-8

58. Baubler E, Coupar IM, Hardcastle J, Hardcastle PT. Stimulatory effects of 5-hydroxytryptamine on fluid secretion and transmural potential difference in rat small intestine are mediated by different receptor subtypes. J Pharm Pharmacol 1990;42:35-9.

59. Beubler E, Kollar G, Saria A, Bukhave K, Rask-Madsen J. Involvement of 5-hydroxytryptamine, prostaglandin 
$\mathrm{E}_{2}$, and cyclic adenosine

monophosphate in cholera-induced

fluid secretion in the small intestine of

the rat in vivo. Gastroenterology

1989;96:368-76.

60. Sjogren RW, Sherman PM, Boedeker EC. Altered intestinal motility precedes diarrhea during Escherichia coli enteric infection. Am J Physiol 1989;257:G725-31

61. Crissinger KD, Granger DN. Intestinal blood flow and oxygen consumption:

Responses to hemorrhage in the developing piglet. Pediatr Res 1989;26:102-5.

62. Crissinger KD, Granger DN. Characterization of intestinal collateral blood flow in the developing piglet. Pediatr Res 1988:24:473-6.

63. Crissinger KD, Granger DN. Mucosal injury induced by ischemia and reperfusion in the piglet intestine. Influences of age and feeding. Gastroenterology 1989;97:920-6.

64. Mangino MJ, Anderson CB, Murphy MK, et al. Mucosal arachidonate metabolism and intestinal ischemiareperfusion injury. Am J Physiol 1989;257:G299-307.

65. Zimmerman BJ, Grisham MB, Granger DN. Role of oxidants in ischemia/ reperfusion-induced granulocyte infiltration. Am J Physiol 1990;258:G185-90.

66. Vohra K, Rosenfeld W, Singh I, Anderson V. Ischemic injury to newborn rabbit ileum. Protective role of human superoxide dismutase. J Pediatr Surg 1989;24:893-8.

67. Cronin CMG, Canose J, Buchanan D, Holzman IR. The effect of aminophylline on gastrointestinal blood flow and oxygen metabolism in the conscious newbom lamb. J Pediatr Gastroenterol Nutr 1989;8:371-5.

68. Rozsa Z, Jacobson ED. Capsaicinsensitive nerves are involved in bileoleate-induced intestinal hyperemia. Am J Physiol 1989;256:G476-81.

69. Chou CC, Alemayehu A, Mangino MJ. Prostanoids in regulation of postprandial jejunal hyperemia and oxygen uptake. Am J Physiol 1989;257:G798-808.

70. Sawmiller DR, Chou CC. Jejunal adenosine increases during foodinduced jejunal hyperemia. Am ] Physiol 1990;G370-6.

71. Rakugi H, Nakamaru M, Tabuchi Y, et al. Endothelin stimulates the release of prostacyclin from rat mesenteric arteries. Biochem Biophys Res Comm 1989;160:924-8.

72. Plonka AJ, Schentag JJ, Messinger S, et al. Effects of enteral and intravenous antimicrobial treatment on survival following intestinal ischemia in rats. J Surg Res 1989;46:216-20.
73. Garcia JG, Rollan CM, Enrinquez AR, et al. Improved survival in intestinal ischemia by allopurinol not related to xanthine-oxidase inhibition. J Surg Res 1990;48:144-6.

74. Saraga EP, Costa J. Idiopathic entero-colic lymphocytic phlebitis. Am J Surg Pathol 1989;13:303-8.

75. Lilly MP, Harward TRS, Flinn WR. Duplex ultrasound measurement of changes in mesenteric flow velocity with pharmacologic and physiologic alteration of intestinal blood flow in man. J Vasc Surg 1989;9:18-25.

76. Holmes R, Lobley RW. Intestinal brush border revisited. Gut 1989;30:1667-78.

77. Thomson ABR, Keelan M, Sigalet DL, Fedorak RN, Garg ML, Clandinin MT. Patterns, mechanisms and signs for intestinal adaptation. Dig Dis 1990;8:99-111.

78. Garg ML, Thomson ABR, Clandindin MT. Effect of dietary fish oil on tissue lipid metabolism. In: Chandra RK, ed. Health Effects of Fish and Fish Oils. St John's: ARTS Biomedical Publishers, 1989:53-79.

79. Garg ML, Keelan M, Thomson ABR, Clandinin MT. Fatty acid desaturation in the intestinal mucosa. Biochim Biophys Acta 1988;958:139-41.

80. Garg ML, Keelan M, Werizbicld AA, Thomson ABR, Clandinin MT. Regional differences in lipid composition and incorporation of saturated and unsaturated fatty acids into microsomal membranes of rat small intestine. Can J Physiol Pharmacol 1988;66:794-800.

81. Thomson ABR, Keelan M, Lam T, Cheeseman Cl, Walker K, Clandinin MT. Saturated fatty acid diet prevents radiation-associated decline in intestinal uptake. Am J Physiol 1989;256:G178-87.

82. Thomson ABR, Keelan M, Garg ML, Clandinin MT. Influence of dietary fat composifion on intestinal absorption in the rat. Lipids 1989;24:494-501.

83. Thomson ABR, Keelan M, Garg ML, Clandinin MT. Fish oil prevents effect of high cholesterol diet on active intestinal transport of galactose. Can ] Physiol Pharmacol 1989;67:829-36.

84. Garg ML, Keelan M, Thomson ABR, Clandinin MT. Intestinal microsomes. polyunsaturated fatty acid metabolism and regulation of enterocyte transport properties. Can J Physiol Pharmacol 1990;68:636-41

85. Maxton DG, Cynk EU, Jenkins AP, Thompson RPH. Effect of dietary fat on the small intestinal mucosa. Gut 1989;30:1252-5

86. Van Voorhis K, Said HM, Abumrad $\mathrm{N}$, Ghishan FK. Effect of chemically induced diabetes mellitus on glutamine transport in rat intestine. Gastroenterology 1990;98:862-6.

87. O'Dwyer ST, Smith RJ, Hwang TL, Wilmore DW. Maintenance of small bowel mucosa with glutamineenriched parenteral nutrition. JPEN 1989;13:579-85.

88. Mailman D, Womack WA, Kvietys PR, Granger DN. Villous motility and unstirred water layers in canine intestine. Am J Physiol 1990;258:G238-46

89. Daniel H, Fett C, Kratz A. Demonstration and modification of intervillous $\mathrm{pH}$ profiles in rat small intestine in vitro. Am J Physiol 1989;257:G489-95.

90. Stewart CP, Tumberg LA A microelectrode study of responses to secretagogues by epithelial cells on villus and crype of rat small intestine. Am J Physiol 1989;257:G334-43.

91. Weinman MD, Allan CH, Trier JS, Hagen S]. Repair of microvilli in the rat small intestine after damage with lectins contained in the red kidney bean. Gastroenterology 1989;97:1193-204.

92. Weiser MM, Sykes DE, Killen PD. Rat intestinal basement membrane synthesis. Epithelial versus nonepithelial contributions. Lab Invest 1990;62:325-30.

93. Bissonnette R, Lee M-J, Wang E. The differentiation process of intestinal epithelial cells is associated with the appearance of statin, a non-proliferation-specific nuclear protein. J Cell Science 1990;95:247-54.

94. Thomson ABR. Diabetic enteropathy. In: Gitnick G, ed. Principles and Practice of Gastroenterology and Hepatology. New York: Elsevier, 1988:333-43.

95. Debnam ES, Ebrahim HY. Diabetes mellitus and the sodium electrochemical gradient across the brush border membrane of rat intestinal enterocytes. J Endocrinol 1989;123:453-9.

96. Debnam ES, Ebrahim HY. Autoradiographic localization of $\mathrm{Na}$-dependent L-valine uptake by the jejunum of streptozotocin-diabetic rats. Eur J Clin Invest 1990;20:61-5.

97. Duan R-D, Poensgen J, Wicker C et al. Increase in pancreatic lipase and trypsin activity and their mRNA levels in streptozotocin-induced diabetic rats. Dig Dis Sci 1989;34:1243-8.

98. Hartnell JM, Storrie MC, Mooradian AD. Diabetes-related changes in chromatin structure of brain, liver and intestinal epithelium. Diabetes 1990;39:348-53.

99. Whitehead WE, Bosmajian L. Zonderman AB, et al. Symptoms of psychologic distress associated with 
irritable bowel syndrome.

Gastroenterology 1988;95:709-14.

100. Drossman DA, McKee DC, Sandler RS, et al. Psychosocial factors in the irritable bowel syndrome.

Gastroenterology 1988;95:701-8.

101. Clouse RE, Lustman PJ.

Gastrointestinal symptoms in diabetic patients: Lack of association with neuropathy. Am J Gastroenterology 1989;84:868-72.

102. Rao RK, Koldosky O, Davis TP. Inhibition of intestinal degradation of somatostatin by rat milk. Am J Physiol 1990;258:G426-31.

103. Weaver LT, Gonnella PA, Israeel EJ, Walker WA. Uptake and transport of epidermal growth factor by the small intestinal epithelium of the fetal rat. Gastroenterology 1990;98:828-37.

104. Scheving LA, Shiurba RA, Nguyen TD, Gray GM. Epidermal growth factor receptor of the intestinal enterocyte. J Biol Chem 1989:264:1735-41.

105. Naughton CA, Chandler CI, Duplantier RB, Halsted CH. Folate absorption in alcoholic pigs: In vitro hydrolysis and transport at the intestinal brush border membrane. Am J Clin Nutr 1989;50:1436-41.

106. Schedl HP, Wilson HD, Mathur SN, Murthy S, Field FJ. Effects of phospholipid or cholesterol enrichment of rat intestinal brush border membrane on membrane order and transport of calcium. Metabolism 1989;38:1164-9.

107. Pansu D, Bellaton C, Roche C, Brenner F. Theophylline inhibits transcellular Ca transport in intestine and $\mathrm{Ca}$ binding by CaBP. Am J Physiol 1989;257:G935-43

108. Favus MJ, Tembe V, Tanklefsky MD, Ambrosic KA, Nellans HN. Effects of quinacrine on calcium active transport by rat intestinal epithelium. Am J Physiol 1989;257:G818-22.

109. Ghishan FK, Arab N, Nylander W. Characterization of calcium uptake by brush border membrane vesicles of human small intestine. Gastroenterology 1989;96:122-9.

110. Karbach U, Rummel W. Cellular and paracellular magnesium transport across the terminal ileum of the rat and its interaction with the calcium transport. Gastroenterology 1990;98:985-92.

111. Jungbluth $\mathrm{H}$, Binswanger $\mathrm{U}$. Unidirectional duodenal and jejunal calcium and phosphorus transport in the rat. Effects of dietary phosphorus depletion, ethane-l-hydroxy-1,1diphosphonate and 1,25 dihydroxycholecalciferol. Res Exp Med 1989;189:439-49.

112. Tomon M, Tenenhouse HS, Jones G. 1,25-dihydroxyvitamin $\mathrm{D}_{3}$-inducible catabolism of vitamin D metabolites in mouse intestine. Am J Physiol 1990;258:G557-63.

113. Danisi G, Caverzasio J, Trechsel U, et al. Phosphate transport adaptation in rat jejunum and plasma level of 1.25-dihydroxyvitamin $\mathrm{D}_{3}$. Scand J Gastroenterol 1990;25:210-5.

114. Raja KB, Simpson RJ, Peters TJ. Membrane potential dependence of Fe(III) uptake by mouse duodenum. Biochim Biophys Acta 1989;984:262-6.

115. Kawakami H, Dosako S, Lönnerdal B. Iron uptake from transferrin and lactoferrin by rat intestinal brush-border membrane vesicles. Am J Physiol 1990;258:G535-41.

116. Whittaker P, Skikne B, Covell A, et al. Gut proteins and hemochromatosis. J Clin Invest 1989;83:261-7.
117. Anderson GJ, Powell LW, Halliday JW. Transferrin receptor distribution and regulation in the rat small intestine. Effect of iron stores and erythropoiesis. Gastroenterology 1990;98:576-85.

118. Lombard M, Bomford AB, Polson RJ Bellingham AJ, Williams R.

Differential expression of transferrin receptor in duodenal mucosa in iron overload. Gastroenterology 1990;98:976-84.

119. Watkins DW, Chenu C, Ripoche P. Zinc inhibition of glucose uptake in brush border membrane vesicles from pig small intestine. Pflugers Arch 1989;415:165-71.

120. Lee HH, Prasad AS, Brewer G], Owyang C. Zinc absorption in human small intestine. Am J Physiol 1989;256:G87-91.

121. Schjonsby H. Vitamin B12 absorption and malabsorption. Gut 1989;30:1686-91.

122. Neale G. B12 binding proteins. Gut 1990;31:59-63.

123. Smolka A, Donaldson RM Jr. Monoclonal antibodies to human intrinsic factor. Gastroenterology 1990;98:607-14.

124. Dix CJ, Hassan IF, Obray HY, Shah R, Wilson $\mathrm{G}$. The transport of vitamin $\mathrm{B}_{12}$ through polarized monolayers of Caco- 2 cells. Gastroenterology 1990;98:1272-9.

125. Ramaswamy M, Alpers DH, Tiruppathi C, Seetharam B. Cobalamin release from intrinsic factor and transfer to transcobalamin II within the rat enterocyte. Am J Physiol 1989;257:G791-7.

126. Stein ED, Diamond JM. Do dietary levels of pantothenic acid regulate its intestinal uptake in mice? J Nutr 1989;119:1973-83. 


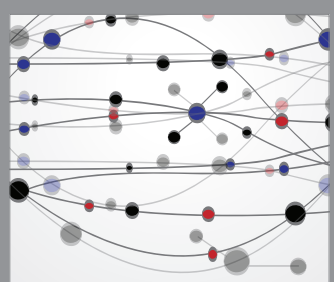

The Scientific World Journal
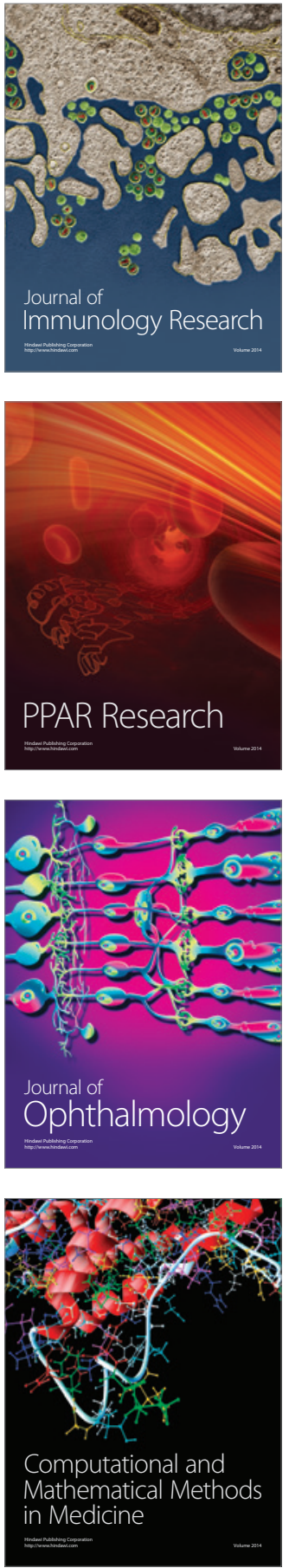

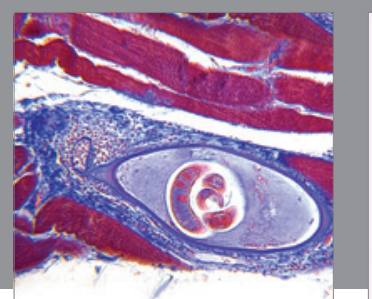

Gastroenterology Research and Practice

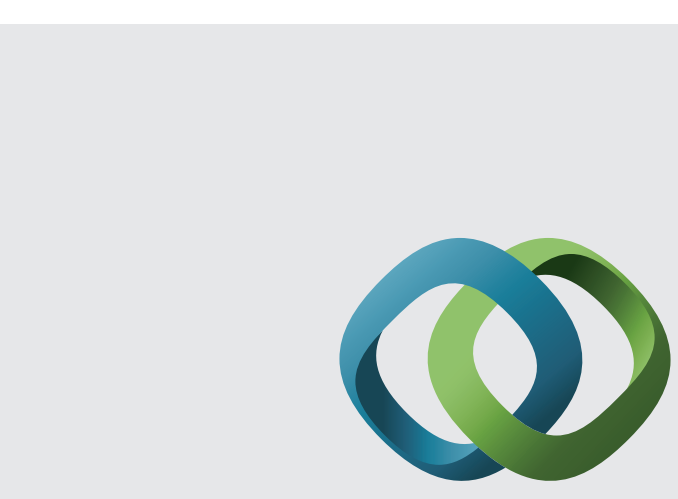

\section{Hindawi}

Submit your manuscripts at

http://www.hindawi.com
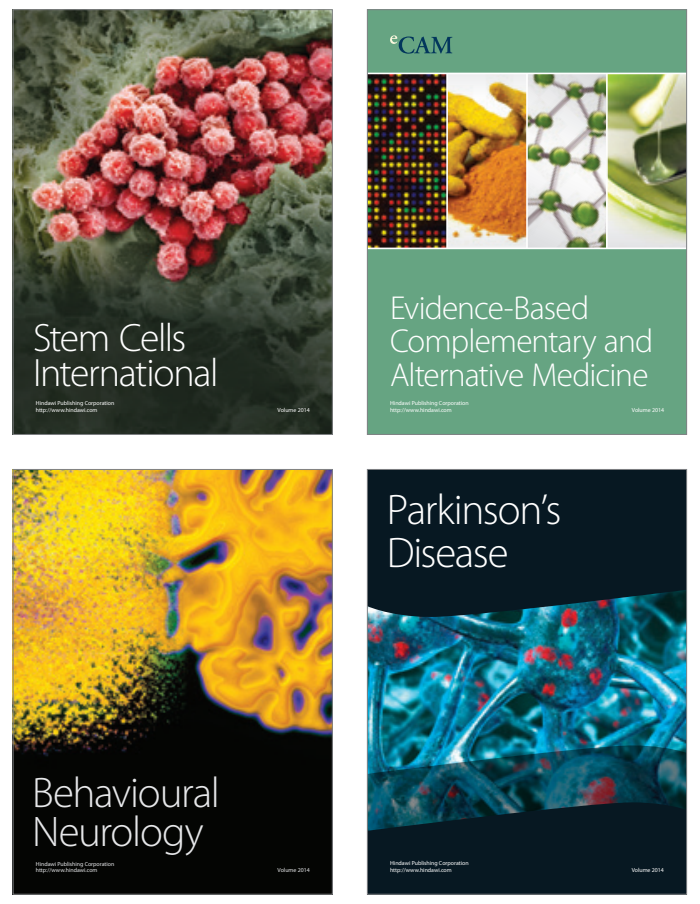
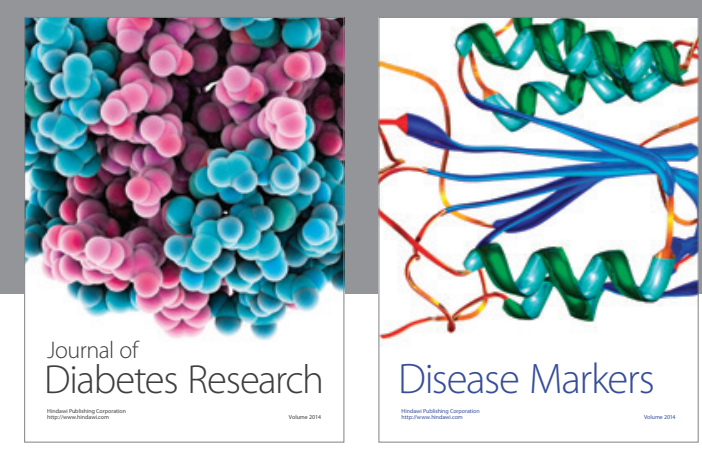

Disease Markers
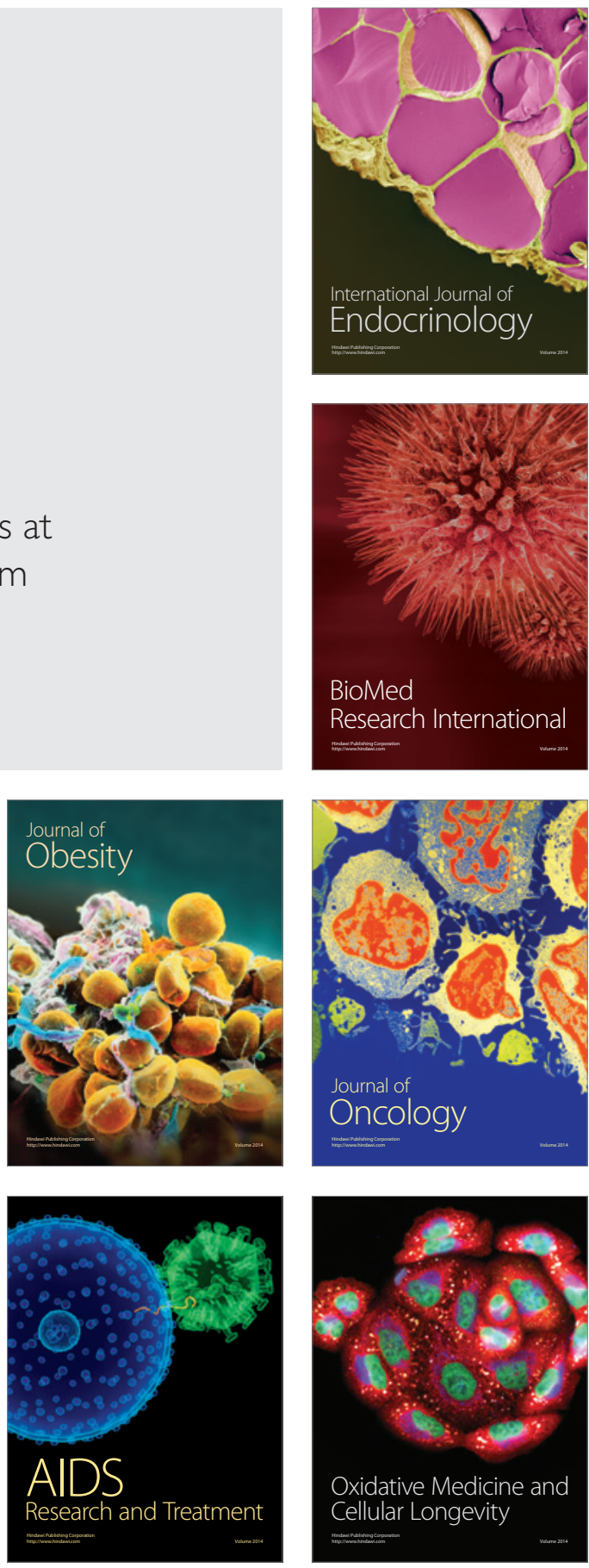